\title{
The ECB's Independence and the Principle of Separation
}

\author{
Pamela Nika ${ }^{1}$
}

Abstract: This article addresses the question of whether the European Central Bank's (ECB's) involvement in banking supervision is compatible with its independent status as provided by the European Union's (EU's) primary law, specifically with reference to the principle of separation between the ECB's monetary policy and supervisory powers. It is found that the Single Supervisory Mechanism (SSM) Regulation provides the ECB with a set of prerequisites in pursuit of its supervisory objectives under a high level of independence. However, the article argues that the current EU regulatory framework poses risks to the overall independence of the ECB. In particular, the principle of separation, as one of the mechanisms aimed at safeguarding the ECB's independence, is not fully achieved. In addition, the boundaries and application of macro-prudential operation of the ECB in both the SSM and European Systemic Risk Board (ESRB) remain blurry and uncertain. The article concludes by suggesting that the only way to safeguard the independence of the ECB is by carefully revising the ECB's competencies, which may require treaty amendment.

Keywords: ECB, Banking Supervision, Banking Supervision Centralization, Prudential Supervision, European Union, EU Law, Banking Union, Central Banking Independence, SSM, SSMR

\section{A Introduction}

Central banks, whether acting as governments' banks and banknotes issuers (in their early years) or operating as politically independent monetary policy authorities (at a later stage), have undisputedly played a key role in supporting the financial and monetary system and industrial development. Indeed, through their monetary policy central banks can determine and control the money supply; influence inflation rates, unemployment and economic growth; and affect financial stability and currency exchange rates. In addition, central banks have always played an important role in the supervision of the financial system, either on their own or in cooperation with other institutions. However, the primacy given to central bank independence in the late 1970s and the banks' increasing role in pursuing the goal of price stability, consolidated their role as monetary policy authorities. This resulted in central banks having a narrow mandate, focused mainly on inflation targeting as the means of achieving price stability, whereas their banking supervision role remained limited. However, as the role and function of central banks was evolving, this orthodoxy concerning the optimal model of central banking has been challenged.

\footnotetext{
${ }^{1}$ Dr Pamela Nika is a lecturer in Corporate and Finance Law at Brunel University London (email: pamela.nika@brunel.ac.uk).
} 
The most recent example of an event, or a series of events, that triggered major institutional changes and regulatory reform was seen in the wake of the great financial crisis (GFC). The GFC began as a crisis in the US housing market in 2007, which soon developed into international financial turmoil following the collapse of Lehman Brothers in September 2008. It was on the brink of failure that a widespread debate started, challenging prevailing notions and mainstream macroeconomic theories. To this end, conventional wisdom in the pre-crisis era required central banks to operate as monetary authorities, independently of political interference, focused primarily on maintaining price stability and with a defined numerical inflation target and regular adjustment of interest rates (usually the short-term interest rate) as their main policy instruments. In the aftermath of the GFC this consensus was questioned, leading to a rethinking of the role, purpose and overall mandate of central banks. In fact, the focus shifted from price stability to financial stability, with the notion of financial stability regaining attention and a 'priority status' within the set of central banks' goals. As a result, policymakers at both national and international levels laid emphasis on the need for a drastic regulatory change that would strengthen central banks' role in both micro- and macro-prudential supervision yet maintain a balance between the objectives of financial stability and price stability.

At the European Union (EU) level, the regulatory response to the GFC focused primarily on reshaping the supervisory architecture, with the European Central Bank (ECB) becoming progressively involved in banking supervision. However, the ECB, since its establishment by the Maastricht Treaty, was conceived as a purely monetary policy authority, while banking supervision remained out of its remit and subject to a strict separation principle. In fact, the institutional framework, the governance structure and the legal basis of the ECB's mandate were all designed to facilitate the functioning of an independent monetary authority entrusted with the sole mandate of price stability, attained through an inflation targeting regime, which was considered to be adequate in safeguarding the stability of the EU financial system as a whole.

Nevertheless, as mentioned previously, the GFC challenged the theoretical foundation of the conventional wisdom and triggered the need for change in the EU regulatory and supervisory frameworks. Starting with the Lamfalussy process, which was followed by the De Larosière Report and a plethora of legislative reforms, the EU financial market regulation and supervision entered an era of Europeanization that led to a significant expansion of the ECB's role; an expansion that was moving beyond its envisioned mandate. This stretching of the ECB's mandate gathered momentum with the establishment of the first pillar of the European Banking Union, the Single Supervisory Mechanism (SSM) in late 2014, which transformed the ECB into the supranational banking supervision authority for the Eurozone's financial institutions. This official assignment of supervisory powers to the ECB has been appraised as the most significant restructuring of central banking architecture in the EU. Thus, it 
is hardly surprising that this radical regulatory reform was accompanied by a very extensive debate in relation to the controversies, synergies and conflict of interest.

This debate has covered a variety of disciplines, including economic, social, political and legal. In the legal context, one of the most debated issues is whether the newly established supervisory tasks of the ECB are compatible with its monetary policy mandate as provided by the existing institutional framework. This is particularly important given the clear hierarchy provided by the treaty provisions to the ECB's objectives and its exclusion from assuming supervisory tasks when they do not classify as 'specific.' It is therefore questionable how the same treaty provisions that were designed to facilitate the functioning of a 'pure' monetary policy authority provided an adequate legal basis for the subsequent stretching of the ECB's mandate to supervision and how they delineate the exact limits of the 'specificity' of supervisory tasks. In addition, the ECB's involvement in banking supervision raises fundamental questions about its independence and the potential conflict of interest with its existing price stability mandate.

The advantages of central bank independence has been advocated widely, including its various types and dimensions. ${ }^{2}$ The ECB, as a creature of its time, has been designed, since its inception, as a highly independent central bank and has indeed been regarded as one of the most independent central banks in the world. ${ }^{3}$ In fact, the ECB's independence is enshrined in EU primary law and therefore enjoys constitutional authority.

The article, after examining the banking supervision centralization at the EU level, goes on to analyse in detail the principle of separation. This is followed by a thorough evaluation of the ECB's independence in both monetary policy and supervision with the aim of addressing the question of whether and to what extent the ECB's independence has been influenced by the advent of the SSM and the marrying of monetary policy and banking supervision objectives. To this end, it finds that the SSM Regulation (SSMR) strives to protect the ECB's independent status by separating the competences of the ECB in the monetary policy and banking supervision domains and also by introducing a host of new bodies that would operate in the supervisory domain. However, housing both banking supervision and monetary policy under the ECB's roof can trigger conflict of interest issues when the ECB will inevitably be confronted with monetary policy choices, especially when the latter are likely to influence

\footnotetext{
${ }^{2}$ See: Alberto Alesina and Roberta Gatti, 'Independent Central Banks: Low Inflation at No Cost?' (1995) 85 (2) The American Economic Review 196; S.C.W. Eijffinger, 'Central Bank Independence: Criteria and Indices' (1995) 14 Kredit und Kapital 185; Alex Cukierman, Steve Web, and Bilin Neyapti, 'Measuring the Independence of Central Banks and Its Effect on Policy Outcomes' (1992) 6 (3) The World Bank Economic Review 353; V. Grilli, D. Masciandaro, and G. Tabellini, 'Political and Monetary Institutions and Public Financial Policies in the Industrial Countries' (1991) 6 (13) Economic Policy 341.

${ }^{3}$ Damien Chalmers, Gareth Davies, and Giorgio Monti, European Union Law (2nd ed, Cambridge University Press 2010), 732.
} 
the soundness of important Eurozone banks. Lastly, the article also considers the ECB's role in microand macro-supervision with a view to evaluating their potential impact on the ECB's independence. More controversial appears to be the role of the ECB in macro-prudential supervision, which has a direct impact on the independent status of the ECB and its responsibility in operating within the limits of its powers as provided by EU primary law. It is suggested that a careful revision of the ECB's competences through EU Treaty changes under the existing framework is warranted. To this end, it is concluded that given the fact that the ECB's independent status is enshrined in EU primary law, any change will require a treaty amendment.

\section{B The Centralization of Banking Supervision at EU Level}

It is well known that the impetus for banking supervision centralization at the EU level came from the events surrounding the occurrence of the GFC. However, although the process of broadening the ECB mandate towards an increasing involvement in banking supervision reached its peak in the post GFC era, it had already begun in the early 2000s. In particular, one of the milestones was the Lamfalussy Report in 2004, ${ }^{4}$ which led to the creation of a mechanism of four levels of governance for the regulation and supervision of the EU financial services market. ${ }^{5}$ However, in light of the GFC, the EU Commission, in its communication of 29 October 2008, initiated work on the EU supervisory arrangements that were to be carried out by a high-level expert group - the so-called De Larosière Group. ${ }^{6}$ The De Larosière Group produced a report in $2009,{ }^{7}$ leading to an updated version of the original four-level mechanism and to the creation of the ESRB in 2011, which was entrusted with the macro-prudential oversight of the euro area banks.

Despite these attempts to strengthen the regulatory and supervisory framework, the first half of 2012 - right before the introduction of the SSM - found Europe in the middle of one of the most severe economic disruptions in its history. Many EU countries were experiencing severe sovereign debt crises, and major banking groups were facing liquidity problems and were struggling to meet their short-term

\footnotetext{
${ }^{4}$ European Commission, 'White Paper on Completing the Internal Market', COM (1985) 310 final (14 June 1985), http://aei.pitt.edu/1113/1/internal_market_wp_COM_85_310.pdf_accessed 25 September 2020).

${ }^{5}$ Philipp Hartmann et al., 'The Euro Area Financial System: Structure, Integration and Policy Initiatives', ECB Working Paper No. 230 (May 2003), 39, www.ecb.europa.eu/pub/pdf/scpwps/ecbwp230.pdf (accessed 25 September 2020).

${ }^{6}$ European Commission, 'From Financial Crisis to Recovery: A European Framework for Action' COM (2008) 706 final, 4, http://eur-lex.europa.eu/legal-content/EN/TXT/PDF/?uri=CELEX:52008DC0706\&from=EN (accessed 20 September 2020).

${ }^{7}$ The de Larosière Group, 'Report by the High Level Group on Financial Supervision in the EU', (2009), http://ec.europa.eu/economy_finance/publications/pages/publication14527_en.pdf (accessed 25 September 2020).
} 
liabilities. ${ }^{8}$ Thus, a strong need to deepen Europe's Economic and Monetary Union (EMU) came to the fore, while any political resistance of the past was slowly diminishing. In response to this realization, in June 2012, the President of the EU Council at the time, Herman Van Rompuy, announced that the EU was willing to move towards the establishment of a genuine European Banking Union. ${ }^{9}$ The objective of creating a banking union was to elevate supervision, recapitalization, resolution and deposit protection at the EU level, all based on a single rule book. As was mentioned by the Herman Van Rompuy Report, 'an integrated financial framework should have two central elements: single European banking supervision and a common deposit insurance and resolution framework'. ${ }^{10}$ Shortly after, the Euro Area Summit Statement specified the mandate given to the EU Commission to present a proposal on the basis of Article 127(6) TFEU for the creation of an SSM. ${ }^{11}$ The EU Commission's response came in September 2012 by introducing a communication, explaining the rationale for the creation of a banking union for Europe, while laying the groundwork for its completion; ${ }^{12}$ a proposal for the creation of SSM, ${ }^{13}$ formed by the ECB and National Competent Authorities (NCAs) $;{ }^{14}$ and a proposal for the amendment of the EBA Regulation, ${ }^{15}$ intended to amend the existing role of EBA in accordance with the new supervisory framework.

This process led to the establishment of the SSM, which became fully operational on 4 November 2014, conferring specific prudential supervision tasks on the ECB. Thus, pursuant to the SSM, the ECB became the central prudential supervisor of Eurozone financial institutions. The SSM represents the first pillar of the wider European Banking Union project, while the other two are a common framework for recovery and resolution (the Single Resolution Mechanism - SRM) and for deposit protection (the European Deposit Insurance Scheme - EDIS). The SRM was implemented in July 2014 and came into force in August 2016, whereas the EDIS was subject to the EU Commission's proposal in November 2015 but has not been implemented yet.

\footnotetext{
${ }^{8}$ In early 2010 the Greek sovereign debt crisis became apparent, and many countries were experiencing serious financial circumstances: Ireland, Portugal, Italy and Spain.

${ }^{9}$ Herman Van Rompuy, Towards a Genuine Economic and Monetary Union (26 June 2012), Presse 296, www.consilium.europa.eu/uedocs/cms_data/docs/pressdata/en/ec/131201.pdf_(accessed 25 September 2020).

${ }^{10}$ Ibid 4.

${ }^{11}$ Euro Area Summit Statement (29 June 2012), www.consilium.europa.eu/uedocs/cms_data/docs/pressdata/en/ec/131359.pdf (accessed 25 September 2020). ${ }^{12}$ European Commission, 'A Roadmap towards a Banking Union', COM (2012) 510 final, https://eurlex.europa.eu/legal-content/EN/TXT/PDF/?uri=CELEX:52012DC0510\&from=EN (accessed 25 September 2020).

${ }^{13}$ Ibid.

${ }^{14}$ Ibid 7.

${ }^{15}$ European Commission, 'Proposal for a Council Regulation Conferring Specific Tasks on the European Central Bank Concerning Policies Relating to the Prudential Supervision of Credit Institutions', COM (2012) 511 final, https://eur-lex.europa.eu/legal-content/EN/TXT/PDF/?uri=CELEX:52012PC0511\&from=EN (accessed 25 September 2020).
} 
The SSM is designed to operate within the ECB, with the latter sharing its duties with the NCAs. The ECB directly supervises the significant entities via Joint Supervisory Teams (JST), which comprise staff from both NCAs and the ECB. The NCAs continue to be responsible for the day-to-day supervision of less significant entities that do not fall under the oversight and control of the ECB. In the centre of the SSM operates the Single Supervisory Board (SSB), assisted by a steering committee, and the JST. ${ }^{16}$ The SSB operates within the ECB, encompassing the specific expertise of national supervisors, while serving as the main body responsible for preparing decisions on supervisory matters. ${ }^{17}$ As highlighted by the SSMR, the SSB undertook the prudential supervisory tasks that have been traditionally subject to national discretion, ${ }^{18}$ empowering the ECB with far-reaching supervisory powers. This has triggered a debate over the question of whether the operating structure of the SSM adequately meets the need for safeguarding the ECB's independence, which is at the heart of ECB's constitutional frameworks. Since the latter has remained unchanged, the SSM established a set of mechanisms designed to protect the principle of independence and the legitimacy of ECB's operation, including a strict separation between the ECB's traditional function as monetary policy authority and its newly established supervisory powers.

The centralization of banking supervision at the EU level and, specifically, the empowerment of the ECB with supervisory tasks, raised concerns about the compatibility of the latter with excising treaty provisions. For this reason, before examining the principle of separation, it is important to analyse the legal basis for the SSM establishment and the assumption of supervisory tasks from the ECB. In short, the legal bases of the SSM establishment are the following: Article 127(6) TFEU, which confers regulatory power on the ECB; the SSMR, which assigns the ECB specific regulatory duties; and the SSM Framework Regulation (SSMFR), ${ }^{19}$ which aims to regulate the cooperation and coordination between the ECB and the national supervisors. Although the SSMR and SSMFR are newly adopted, Article 127(6) TFEU traces its roots back to the creation of the EMU. However, although it served as the legal basis of the ECB's newly adopted supervisory power, Article 127(6), TFEU, is worded in a way that does not allow for a direct delegation of supervisory power to the ECB. In fact, starting with the EU primary law, there is no provision that empowers the ECB with any direct supervisory tasks. Thus, in order to understand the use of Article 127(6) TFEU, as the legal basis for the SSM establishment, it is important to appreciate the intended meaning of the provision, which arises from

\footnotetext{
${ }^{16}$ European Council, 'Regulation 1024/2013 of October 15, 2013 Conferring Specific Tasks on the European Central Bank concerning Policies relating to the Prudential Supervision of Credit Institutions', (2013), O.J. L 287/63 [hereinafter: SSMR] Rec. (71).

${ }^{17}$ SSMR Recs. (67) and (69).

${ }^{18}$ SSMR Rec. (69).

${ }^{19}$ Regulation (EU) No 468/2014 of the European Central Bank of 16 April 2014, establishing the framework for cooperation within the Single Supervisory Mechanism between the European Central Bank and national competent authorities and with national designated authorities ECB/2014/17 [2014] OJ L 141/1 [hereinafter: SSMFR].
} 
the rationale behind its adoption, the historical background of its formulation and the reasoning behind its wording.

Going back to the genesis of the EMU, the draft report of the Delors Committee provided the following definition: 'the system would participate in the coordination of banking supervision policies of the national supervisory authorities.' However, in the final report, although prudential supervision was included among the basic functions of the European System of Central Banks (ESCB), the term 'national' was removed as follows: 'the System would participate in the coordination of banking supervision policies of the supervisory authorities, ${ }^{, 20}$ which suggests that the supervisory authorities could be supranational/European. ${ }^{21}$ Furthermore, the ESCB was assigned prudential supervisory responsibilities in the first draft statute, ${ }^{22}$ defining that the ESCB shall (note: not the ECB alone) 'participate as necessary in the formulation, co-ordination and execution of policies relating to prudential supervision and the stability of the financial system'. ${ }^{23}$ However, the final version of the ESCB Statute did not include prudential supervision as one of the basic tasks of the ESCB. ${ }^{24}$ This can also be explained by the strong opposition led, primarily, by the German Bundesbank, which stressed the issue of a possible conflict of interest between the supervisory and monetary policy tasks if the two were to be brought under the umbrella of the same authority. ${ }^{25}$ Therefore, it is reasonable to argue that the intention to include prudential supervision among the basic tasks of the ECB was clearly expressed by the EU policymakers; an intention that, however, never came to be implemented owing to failure to reach a political agreement.

As a result, neither Article 127(6) TFEU nor Article 25 ESCB Statute, assigned to the ECB direct prudential supervisory duties. In fact, according to Article 25 ESCB Statute, the ECB was granted only specific tasks in relation to prudential supervision of financial institutions ${ }^{26}$ as well as consulting and advisory duties in this area. ${ }^{27}$ However, according to Article 127(6) TFEU, the ECB may be granted 'specific tasks concerning the policies relating to the prudential supervision of credit institutions and

20 'Report on economic and monetary union' (Committee for the Study of Economic and Monetary Union chaired by Jacques Delors, 1989) (hereinafter: the Delors Report) 22, Para. 32, http://ec.europa.eu/economy_finance/publications/pages/publication6161_en.pdf (accessed 25 September 2020). ${ }^{21}$ James Harold, 'International Cooperation and Central Banks', in Youssef Cassis, Richard Grossman and Catherine Schenk (eds.), The Oxford Handbook of Banking and Financial History (2nd edn., Oxford University Press 2016) 364, 381-382.

${ }^{22}$ For a detailed analysis of the interpretation of the articles of the draft statute see: Rene Smits, The European Central Bank: Institutional Aspects (Kluwer Law International 1997).

${ }^{23}$ 'Draft Statute of the European System of Central Banks and of the European Central Bank: Introductory Report and Commentary' (Central Banks Governors, 8 December 1990, Brussels) 3.

${ }^{24}$ Consolidated version of the Treaty on the Functioning of the European Union' [2012] OJ C 326/47 (hereinafter: TFEU) Art. 127(2) TFEU.

${ }^{25}$ Harold (n 21) 382.

26 'Protocol (No 4) On the Statute of the European System of Central Banks and of the European Central Bank' [2016] OJ C202/230 www.ecb.europa.eu/ecb/legal/pdf/oj_c_2016_202_full_en_pro4.pdf (accessed 25 September 2020) (hereinafter: ESCB Statute), Art. 25(2).

${ }^{27}$ Ibid., Art. 25(1). 
other financial institutions with the exception of insurance undertakings ${ }^{9}{ }^{28}$ this wording clearly left space for further interpretation as to the potential involvement of the ECB in prudential supervision. ${ }^{29}$ This is also known as the enabling clause, which was activated, initially, to confer prudential supervision tasks on the ECB within the context of ESRB and, subsequently, for the adoption of the SSMR, assigning supervisory tasks to the ECB.

However, the interpretation of Article 127(6) TFEU is far from straightforward. Views are divided between those supporting the narrow interpretation of the provision and those advocating a wider reading. In the first category belonged those who supported an advisory role for the ECB in prudential supervision ${ }^{30}$ and in the second category those who advocated that the enabling clause of Article 127(6) TFEU leaves space for a broader interpretation, allowing for a possible conferral of supervisory tasks on the ECB. ${ }^{31}$ Arguments against the idea that Article 127(6) TFEU constitutes a sufficient legal basis for the establishment of the SSM concentrate on the wording of the provision. In particular, based on this view the ECB can be conferred only 'specific tasks concerning the policies relating to the prudential supervision of credit institutions'. According to this interpretation, the phrase 'the specific tasks' refers to limited responsibilities with no space intended for a possible conferral of prudential supervisory responsibilities on the ECB. Moreover, since the wording of Article 127(6) TFEU clearly refers to 'tasks,' the conferral of 'powers' seems to exceed the intended meaning of the provision.

This view finds further support for the wording of Article 25 ESCB Statute, which, as mentioned earlier, entrusts the ECB with advisory and consultancy duties in relation to prudential supervision, yet without providing for any direct supervisory competence. Indeed, this provision, if read in conjunction with Article 127(6) TFEU, suggests that the role of the ECB in prudential supervision remains advisory and supportive. Moreover, according to Article 127(5) TFEU, '[T]he ESCB shall contribute to the smooth conduct of policies pursued by the competent authorities relating to the prudential supervision of credit institutions and the stability of the financial system. ${ }^{32}$ Hence, it can be argued that since this provision refers to the conduct of 'policies', it practically makes reference to the Reports and Studies published by the ECB and the examination or review of prudential supervisory operation undertaken by other entities (i.e. NCAs, European Banking Authority (EBA), Economic and

\footnotetext{
${ }^{28}$ TFEU (n 24) Art. 127(6).

${ }^{29}$ Rosa Lastra, 'The Division of Responsibilities between the European Central Bank and the National Central Banks within the European System of Central Banks' (2000) 6 (2) Columbia Journal of European Law 167, 174.

${ }^{30}$ For the argument in favour of the narrow interpretation see: Elliot Posner, 'The Lamfalussy Process: Polyarchic Origins of Networked Financial Rulemaking in the EU', in Charles F. Sabel and Jonathan Zeitlin (eds.), Jonathan Experimentalist Governance in the European Union: Towards a New Architecture (Reprint edn, Oxford University Press 2012).

${ }^{31}$ For arguments in favour of the wider interpretation: Lastra (n 29), Smits (n 22) and Larisa Dragomir, European Prudential Banking Regulation and Supervision: The Legal Dimension (Reissue edn, Routledge 2012).

${ }^{32}$ Emphasis added
} 
Financial Committee (EFC) and Financial Services Committee (FSC)). Accordingly, the 'specific tasks' of Article 127(6) TFEU are to be interpreted as closely related to the conduct of those policies, which serve mainly a supportive and advisory role rather than a supervisory role. ${ }^{33}$ Moreover, according to Article 13(2) TEU, 'Each institution shall act within the limits of the powers conferred on it in the Treaties, and in conformity with the procedures, conditions and objectives set out in them, ${ }^{34}$ and since the ECB was not granted any direct supervisory powers by the EU Treaties, it is questionable whether Article 127(6) TFEU can be considered as an adequate legal basis for the assignment of supervisory tasks to the ECB.

On the other hand, among the arguments supporting the view that Article 127(6) TFEU constitutes an adequate legal basis for the conferral of supervisory powers on the ECB were those who held that the wording of the provision, in fact, suggests a broader interpretation. Specifically, it has been argued that Article 127(6) TFEU contains an enabling clause that allows the conferral of supervisory powers on the ECB without requiring a formal amendment of the treaty. ${ }^{35}$ Another argument in favour of this view is the fact that the supervisory powers conferred on the ECB with the SSMR are limited to being 'specific' and thus compatible with the wording of the provision. To this end, first, the supervisory tasks of the ECB are limited geographically, applying as they do only to financial institutions of Eurozone Member States, and second, they are limited in scope in that the ECB is entrusted only with prudential supervisory tasks. ${ }^{36}$

Given the historical background of Article 127 TFEU, its rationale and the first draft of the ESCB Statute (with its intention to include prudential supervision among the basic tasks of the ECB), it would be unrealistic to accept a narrow interpretation of its meaning. Even if one focuses only on the vaguely formulated wording of the provision, although it reflects a limited scope of the intended meaning, one could say that it indeed leaves space for broad interpretation. Furthermore, given the importance of the issue of prudential supervision in the EU financial architecture, which is evident from the reference made even during the very early discussions of the EMU creation - since the drafting of

\footnotetext{
${ }^{33}$ Anita Millar, 'EU Banking Union-Operational Issues and Design Considerations', (2012), Report prepared for the International Regulatory Strategy Group, https://www.admadvisory.com/wp-content/uploads/2020/01/EUbanking-unions-final3.pdf (accessed 20 September 2020).

${ }^{34}$ The ECJ has repeatedly emphasized in a number of cases that each institution is to act within the limits of the powers conferred upon it by the treaty. See the following rulings:

- $\quad$ Case C-93/00 Parliament v. Council [2001] ECR I-10119, Para. 39;

- $\quad$ Case C-110/03 Belgium v. Commission [2005] ECR I-2801, Para. 57;

- $\quad$ Case C-403/05 Parliament v. Commission [2007] ECR I-0000, Paras. 49; and

- $\quad$ Case C-133/06 European Parliament v. Council [2008] ECR I-3189, Para. 44.

However, the rules regarding the manner in which the Community institutions arrive at their decisions are laid down in the treaty and are not at the disposal of the member states or of the institutions themselves. See: Case C133/06, Para. 54 and Case 68/86 United Kingdom v. Council [1988] ECR 855, Para. 38.

${ }^{35}$ Dragomir (n 31) 174.

${ }^{36}$ See: Klaus Lackhoff, 'How Will the Single Supervisory Mechanism (SSM) Function? A Brief Overview' (2014) 29 (1) Journal of International Banking Law and Regulation 13.
} 
the Maastricht Treaty - it would be sensible to believe that the EU policymakers' intention was to empower the ECB with supervisory tasks. This idea at the time, however, was immature and subject to political tensions that made its final implementation unachievable. This perhaps explains the vague formulation of Article 127(6) TFEU, which indeed leaves 'space' for a broad interpretation. To this end, there are strong arguments supporting the view that this 'space' was intentionally neglected in order to leave the option open for the EU Council's consideration in the future. ${ }^{37}$

Apart from the doubts raised in relation to Article 127(6) TFEU and its adequacy as the legal basis for the ECB's involvement in banking supervision, when interpreting the new supervisory tasks of the ECB, the principle of conferral, including subsidiarity and proportionality, should be taken into consideration. Specifically, with reference to Article 5(2) TEU, the ECB tasks should be interpreted within the limits of its objectives as were set by primary EU law, and in accordance with the principles of subsidiarity and proportionality. ${ }^{38}$ It is, therefore, hardly surprising that the principles of subsidiarity and proportionality were applied, accordingly, to supervisory powers of the ECB's. To this end, the supervisory powers of the ECB may apply only to the extent that they cover aspects that cannot be sufficiently monitored at the national level or because it has been acknowledged that the common objectives of the conferred powers can be achieved better at the EU level. Hence, the SSMR has endorsed the principle of subsidiarity and proportionality, by pointing out that the objectives of the conferred powers:

cannot be sufficiently achieved at the Member State level and can therefore, by reason of the pan-Union structure of the banking market and the impact of failures of credit institutions on other Member States, be better achieved at the Union level, the Union may adopt measures, in accordance with the principle of subsidiarity as set out in Article 5 TEU. In accordance with the principle of proportionality, as set out in that Article, this Regulation does not go beyond what is necessary in order to achieve those objectives ${ }^{39}$

Furthermore, the fact that the supervisory tasks conferred to the ECB shall comply with the principles of subsidiarity and proportionally was also affirmed by the Report of the Joint Committee for EU Affairs. $^{40}$

\footnotetext{
${ }^{37}$ Ibid 15.

${ }^{38}$ Treaty on European Union [1992] OJ C191/1 (hereinafter: TEU), http://eur-lex.europa.eu/legalcontent/EN/TXT/PDF/?uri=CELEX:11992M/TXT\&from=EN (accessed 25 September 2020) Arts. 5(3) and (4). ${ }^{39}$ Recital (87) SSMR.

${ }^{40}$ Joint Committee for EU Affairs, 'Report 13/2012 by the Joint Committee for EU Affairs on the Compliance of the Principle of Subsidiarity by the Proposal for a Council Regulation Conferring Specific Tasks on the European Central Bank Concerning Policies Relating to the Prudential Supervision of Credit Institutions', COM (2012) 511 final.
} 


\section{The Principle of Separation Under the SSM Regulation}

Conventional wisdom viewed the combination of monetary policy and banking supervision objectives as non-complementary with a central bank focused on price stability, and thus a strict separation was considered to be the optimal regulatory design. ${ }^{41}$ The rationale behind this view was that the assignment of supervisory tasks to central banks may give rise to conflicts of interest that would undermine the efficient achievement of their core monetary policy objectives. ${ }^{42}$ The ECB, as a creature of its time, ${ }^{43}$ drawing its legal basis from Article 127(6) TFEU, was designed to operate as a 'pure' monetary policy authority with the primary objective of maintaining price stability in the Eurozone, while banking supervision remained at the national level. ${ }^{44}$ The ECB's non-involvement in banking supervision was also meant to serve its independence, which was embedded in the operational structure of the ECB, as provided by EU primary law, and it was reflected in its narrow mandate. The advent of the new supervisory framework, which also draws its legal basis from Article 127(6) TFEU, has shifted the role of ECB to completely different objectives: at the micro level it is the safety and soundness of individual credit institutions and at the macro level the stability of the financial system as a whole. The controversy arising from the combination of all the ECB's operations under the same roof is, therefore, not surprising.

Therefore, this broadening of the ECB's mandate called for the creation of a strict 'Chinese Wall' ${ }^{45}$ between the ECB's monetary policy and supervision mandates, expressed through the principle of separation that is enshrined in Article 25(2) SSMR. The principle of separation requires monetary policy and supervisory tasks to be carried out in full separation, ${ }^{46}$ while 'the tasks conferred on the ECB

\footnotetext{
${ }^{41}$ The separation of the two objectives is based on the so-called Tinbergen Rule, see: John Tinbergen, On the Theory of Economic Policy (2nd edn. North-Holland 1952). See also: Dirk Schoenmaker, 'The Role of Central Banks in Financial Stability', in Gerard Caprio (ed.), The Encyclopedia of Financial Globalization (Elsevier 2011).

${ }^{42}$ For this view see, among others: Charles Goodhart and Dirk Schoenmaker, 'Institutional Separation between Supervisory and Monetary Agencies', in Charles Goodhart (ed.), The Central Bank and the Financial System (Macmillan Press 1993); Sylvester Eijffinger and Rob Nijskens, 'Monetary Policy and Banking Supervision', (2012) European Parliament, Directorate General for Internal Policies, IP/A/ECON/NT/2012-06, www.europarl.europa.eu/studies_(accessed 25 September 2020); Thorsten Beck and Daniel Gros, 'Monetary Policy and Banking Supervision: Coordination Instead of Separation', (2013) CEPS Policy Brief No. 286, http://ssrn.com/abstract=2189364 (accessed 25 September 2020).

${ }^{43}$ For the institutional design of the ECB, see: Smits (n 22) and Chiara Zilioli and Martin Selmayr, The Law of the European Central Bank (Hart Publishing 2001).

${ }^{44}$ Art. 3(1-c) TFEU.

${ }^{45}$ As Schauble's argued back in 2012: 'The EU should create a 'Chinese wall' between the two policies.” As cited at: 'Franco-German rift threatens EU banking union' (Reuters, December 2012), www.reuters.com/article/us-eu-banking-union/franco-german-rift-threatens-eu-banking-unionidUSBRE8B21HG20121204 (accessed 25 September 2020).

46 'Decision of the ECB of 19 February 2004 adopting the Rules of Procedure of the ECB (ECB/2004/2)' [2004] OJ L 80/33 [hereinafter: ECB Rules of Procedure] as amended by, 'Decision of the European Central Bank of 22 January 2014 amending Decision ECB/2004/2 adopting the Rules of Procedure of the European Central Bank
} 
by the SSM shall neither interfere with, nor be determined by, its tasks relating to monetary policy. ${ }^{47}$ Furthermore, as outlined in Article 25(1) SSMR, when acting as supervisor the ECB should perform only the task explicitly conferred on it by the SSMR and 'shall take all necessary measures to ensure separation between the monetary policy and the supervisory functions' ${ }^{48}$ The SSMR requires organizational separation of staff and separate reporting lines. ${ }^{49}$ According to Recital (66) SSMR, the organizational separation of staff 'should concern all services needed for independent monetary policy purposes and should ensure that the exercise of the ... [conferred]... tasks is fully subject to democratic accountability and oversight.' However, in order to avoid an overlap in services, areas of shared responsibilities will be designated, with the aim of supporting both monetary policy and supervision tasks, excluding the information exchange restrictions. ${ }^{50}$

The principle of separation is further regulated by the ECB's Decision of 17 September 2014, which sets out the specific arrangements of the separation between monetary policy and supervision. The principle of separation is also underlined by Article 5, the Code of Conduct for high-level European Central Bank (ECB) Officials. ${ }^{51}$ Moreover, Article 32(1) SSMR, requires the EU Commission to publish reports on the application of SSMR every three years, which should evaluate, inter alia, the effectiveness of the separation between supervisory and monetary policy functions within the ECB and of the separation of financial resources devoted to supervisory tasks from the budget of the ECB. It is clear that much emphasis has laid on the establishment of various mechanisms that would ensure a strict separation between the two policies. It is, however, questionable whether this has been fully achieved. In order to address this question, a detailed analysis of the principle of separation is required.

The separation principle is the main reason for creating a new body (i.e. the SSB) delegated to decide explicitly on supervisory matters. This is aimed at creating a balance, organizational separation and impartial cooperation between the two functions of the ECB. In terms of its composition, the SSB consists of a chair, a (generally non-voting) vice chair, four representatives of the ECB and one representative of each National Central Bank (NCB) or other NCA. ${ }^{52}$ An interesting aspect of the SSB's compositions is the appointment of the chair and vice chair, which, in the initial proposal of the EU

(ECB/2014/1)' [2014] OJ L 95/56; 'Decision (EU) 2015/716 of the ECB of 12 February 2015 amending Decision ECB/2004/2 adopting the Rules of Procedure of the ECB (ECB/2015/8)' [2015] OJ L 114/11; and 'Decision (EU) 2016/1717 of the ECB of 21 September 2016 amending Decision ECB/2004/2 adopting the Rules of Procedure of the ECB (ECB/2016/27)' [2016] OJ L 258/17; Rec. (65) and Art. 25(2) SSMR.

${ }^{47}$ See also: 'Decision of the ECB of Sept. 17, 2014 on the implementation of separation between the monetary policy and supervision functions of the European Central Bank (ECB/2014/39)' [2014] OJ L 300/1 [hereinafter: ECB 2014 Decision] Art. 1(2) and Art. 13k (1) ECB Rules of Procedure.

${ }^{48}$ Art. 13k (2) ECB Rules of Procedure.

${ }^{49}$ Art. 25 (2) (subparagraph 2) SSMR.

${ }^{50}$ Decision Art. 3 (4) ECB 2014.

51 'Code of Conduct for high-level European Central Bank Officials' [2019] OJ C 89/2, https://eurlex.europa.eu/legal-content/EN/TXT/?uri=CELEX\%3A52019XB0308\%2801\%29 (accessed 25 September 2020).

${ }^{52}$ Recs. (67), (69) and Art. 26a SSMR, Art. 13a ECB Rules of Procedure. 
Commission was listed among the responsibilities of the Governing Council. ${ }^{53}$ However, in an attempt to separate the monetary policy function of the Governing Council and its role in prudential banking supervision, this changed. Indeed, the process of appointing the chair and the vice chair of SSB starts with the relevant proposal of the ECB, which then forwards the proposal to the EU Parliament after hearing the SSB,$^{54}$ while the EU Parliament and Council shall be kept informed at all times throughout the selection procedure. ${ }^{55}$ The final decision on the appointment is to be taken by the EU Council with a qualified majority. ${ }^{56}$ The chair is to be selected in an open selection procedure and the vice chair from among the members of the executive board. ${ }^{57}$ Notably, the four representatives of the ECB in the SSM, who are appointed by the Governing Council, have voting rights but shall not be directly involved in monetary policy tasks ${ }^{58}$ whereas the members of the Governing Council are excluded from being appointed as chairs for the SSB. ${ }^{59}$

The decision-making procedure of the SSB is based on the Governing Council's example of the simple majority, with the members having one vote each and the chair a casting vote, ${ }^{60}$ while only a qualified majority is required for draft regulations. ${ }^{61}$ Furthermore, the decision-making process is designed on the basis of a 'non-objection' procedure, ${ }^{62}$ which implies a negative decision of the Governing Council. In particular, when a draft decision of the SSB refers to micro-prudential tasks pursuant to Article 4 SSMR, it should be forwarded to the Governing Council along with explanatory notes, stressing the background and its reasoning and from there to the NCA concerned. ${ }^{63}$ If the Governing Council does not object to the draft decision of the SSB within a maximum of ten working days, ${ }^{64}$ the decision will be considered as an approved decision and thus as adopted. ${ }^{65}$ When the draft decision of the SSB concerns macro-prudential tasks pursuant to Article 5 SSMR, the decision is considered adopted if the Governing Council does not object to it within three working days. ${ }^{66}$ An objection decision of the Governing Council against a draft decision of the SSB that concerns either

\footnotetext{
${ }^{53}$ Rec. (36) and Art. 19(2) SSMR.

${ }^{54}$ Rec. 69 and Art. 26(3) SSMR and Arts. 23(3) and 13b(3) ECB Rules of Procedure.

${ }^{55}$ Rec. (69) and Art. 26(3) SSMR.

56 Art. 26(3) SSMR.

57 Ibid.

${ }^{58}$ Art. 26(5) SSMR and ECB Rules of Procedure Art. 13b (6).

58 Art. 26(3) SSMR.

${ }^{58}$ Art. 26(6) SSMR.

59 Ibid.

${ }^{60}$ Art. 26(6) SSMR.

${ }^{61}$ Art. 26(7) SSMR. For the specific rules applied in regard to qualified majority see also: Art. 13c. ECB Rules of Procedure.

62 'Guide to banking supervision' (ECB, November 2014c), 14, www.bankingsupervision.europa.eu/ecb/pub/pdf/ssmguidebankingsupervision201411.en.pdf (accessed 14 July 2017).

${ }^{63}$ Art. 13g ECB Rules of Procedure.

${ }^{64}$ In emergency circumstances, 48 hours, see Art. 26(8) SSMR and Art. 13g(2) ECB Rules of Procedure.

${ }^{65}$ Art. 26(8) SSMR and Art. 13g(2) ECB Rules of Procedure.

${ }^{66}$ Art. 13h ECB Rules of Procedure.
} 
micro- or macro-prudential tasks shall be justified by providing written reasons, which should raise any monetary policy concerns ${ }^{67}$ and should be forwarded to both the SSB and NCAs. ${ }^{68}$ Moreover, the President of ECB holds the responsibility to explain to the chair of EU Parliament's competent committee, the reasoning underlying the objection. ${ }^{69}$ Therefore, the draft decisions of the SSB are deemed adopted only in the absence of a negative decision from the Governing Council.

Since the Governing Council holds a strong decisive role in both domains (monetary policy and supervisory) it is required to operate in a completely differentiated manner in each domain and shall maintain strictly separated meetings and agendas. ${ }^{70}$ For this purpose, the SSMR requires the SSB to prepare the draft decisions of the Governing Council concerning supervisory matters ${ }^{71}$ but hold a separate meeting agenda and its own members. ${ }^{72}$ In addition, the Governing Council's members and other participants in the SSB meeting are granted an independent status, provided with cooling-off periods, professional secrecy, required to act within the limits of the supervisory task conferred on the ECB by the SSMR and without interfering with the other tasks of the ECB, and shall comply with the rules relating to the separation principle. ${ }^{73}$ The professional secrecy of the SSB's members is further specified by the ECB 2014 Decision, which requires non-disclosure of any information covered by the obligation of professional secrecy from any person involved in supervisory activities. ${ }^{74}$ The professional secrecy obligation applies during or after the termination of their office term and applies to any individual who has 'access to data covered by Union legislation imposing an obligation of secrecy. ${ }^{75}$

Moving beyond the decision-making process, the principle of separation also applies to the information exchanged between the monetary policy and supervision member of staff, which should be done "within the limits and under the conditions set out in the relevant Union legislation" ${ }^{76}$ and shall not exceed the limits of the information necessary for the achievement of the delegated tasks. ${ }^{77}$ This is reinforced by Article 5(1) ECB 2014 Decision, which provides for information exchange only when it is required by EU law and requires that the exchange of confidential information - excluding raw data

\footnotetext{
${ }^{67}$ Art. 26(8) SSMR and Art. 13g(2).

${ }^{68}$ ECB Rules of Procedure Arts. 13g(2) and 13h ECB Rules of Procedure.

69 'Interinstitutional Agreement between the European Parliament and the European Central Bank on the Practical Modalities of the Exercise of Democratic Accountability and Oversight over the Exercise of the Tasks Conferred on the ECB within the Framework of the Single Supervisory Mechanism 2013/694/EU' [2013] OJ L 320/1, Para. 4.

${ }^{70}$ Rec. (65) and Art. 25(3) SSMR and Art. 1(3) ECB 2014 Decision.

${ }^{71}$ Art. 26 SSMR.

${ }^{72}$ Rec. (65) and Art. 25 (24) SSMR.

73 'Code of Conduct for the Members of the Supervisory Board of the European Central Bank' [2015] OJ C 93/2 [hereinafter: SSB Code of Conduct] Art. 3.

${ }^{74}$ Arts. 4(1) and (2) ECB 2014 Decision.

${ }^{75}$ Art. 4(7) ECB 2014 Decision.

${ }^{76}$ Rec. (74) SSMR.

${ }^{77}$ Art. 13k (3) ECB Rules of Procedure.
} 
- should be subject to 'governance and procedural rules' and 'to a need to know' requirement, which shall be demonstrated by the requesting ECB policy function.

The 'need to know' requirement enables the circulation of information when 'necessary for the fulfilments of statutory tasks of the ECB. ${ }^{78}$ The meaning of the term 'need to know' is defined as

the need to have access to confidential information necessary for the fulfilment of a statutory function or task of the ECB, which in case of information labelled as 'ECB-CONFIDENTIAL' shall be broad enough to enable staff to access information relevant to their tasks and take over tasks from colleagues with minimal delays. ${ }^{79}$

Thus, only upon request on a 'need to know' basis, except when required otherwise by EU law, are the monetary policy and supervisory function of the ECB allowed to exchange confidential information; monetary policy in the form of non-anonymized and supervision in the form of anonymized, common reporting and financial reporting. ${ }^{80}$

Also, upon request on a 'need to know basis', when each function operates within the limits of its own objectives and when the executive board provides authorization, the ECB's monetary policy function may exchange information, involving assessments or policy recommendations, with the ECB's supervisory function. ${ }^{81}$ The monetary policy division of the ECB is also entitled to exchange information with the supervisory function, again upon request on 'a need to know basis', when each function acts within the limits of its objectives and there is no information included that involves individual banks or policy-sensitive information related to the preparation of decisions. ${ }^{82}$ Each function holds the right to analyse autonomously and decide on the confidential information received, in accordance with their respective objectives. ${ }^{83}$ In any case, the decision on access to the requested information should be taken by the respective function of the ECB (either monetary policy or supervisor) that owns the relevant information. In case of conflict of interest between the two functions, the executive board is to decide on access to confidential information, yet always in accordance with the principle of separation. ${ }^{84}$ Article 5(3) ECB 2014 Decision takes it a step further by requiring consistency and an obligation to record the decisions of the executive board concerning access to

\footnotetext{
78 Art. 2(2) ECB 2014 Decision.

${ }^{79}$ Ibid.

${ }^{80}$ Art. 6(1) ECB 2014 Decision.

${ }^{81}$ Art. 6(2)(subparagraph 1). ECB 2014 Decision.

${ }^{82}$ Art. 6(2)(subparagraph 2).ECB 2014 Decision.

${ }^{83}$ Art. 6(3) ECB 2014 Decision.

${ }^{84}$ Art. 5(3) ECB 2014 Decision.
} 
information. Lastly, in case of an emergency, as specified by Article 114 of CRD IV, ${ }^{85}$ both functions should exchange information only as long as they act within the limits of this emergency. ${ }^{86}$

Among the tools intended to support the separation principle is the Mediation Panel, which is another body created with a view to further enhancing the strict line drawn between monetary policy and banking supervision objectives of the $\mathrm{ECB} .{ }^{87}$ The main responsibility of the Mediation Panel is to resolve differences that may arise between the Governing Council and the SSB from both monetary and supervisory responsibilities of the ECB. As already discussed, the Governing Council holds the right to object to a draft decision proposed by the SSB. ${ }^{88}$ In case this happens, the NCA concerned is given the right to express its opposition on the Governing Council's objection decision before the Mediation Panel. ${ }^{89}$ The Mediation Panel is chaired by the vice chair of the $\mathrm{SSB}^{90}$ and is composed of one representative from each participating Member State, chosen from among the members of the Governing Council and the SSB, and decided in a simple majority with one vote each. ${ }^{91}$

From the foregoing analysis, it is clear that much attention has been paid to separating the monetary and supervisory tasks of the ECB, in line with EU law and the balance of powers within and outside the ECB structure. However, this has resulted in the creation of a complex system, which marries coordination and separation within two layers of decision making and reposting, two groups of different staff and two distinct meeting agendas. The only limit, in regard to the strict separation between the supervisory and monetary policy powers of the ECB, is the obligation of information exchange. ${ }^{92}$

It is apparent that despite this genuine attempt to separate the decision-making processes of the two bodies, the Governing Council ${ }^{93}$ would still remain the ultimate decision-making body of the ECB. Indeed, in accordance with Article 129(1) TFEU, ${ }^{94}$ the decision-making bodies of the ECB are the

\footnotetext{
${ }^{85}$ Directive 2013/36/EU of the European Parliament and of the Council of 26 June 2013 on access to the activity of credit institutions and the prudential supervision of credit institutions and investment firms, amending Directive 2002/87/EC and repealing Directives 2006/48/EC and 2006/49/EC, 2013 O.J. (L 176) 338 [hereinafter: CRD IV]. ${ }^{86}$ Art. 8 ECB 2014 Decision.

${ }^{87}$ Rec. (73) SSMR.

${ }^{88}$ Art. 26(8) SSMR.

${ }^{89}$ Art. 25(5) SSMR

${ }^{90}$ Regulation (EU) No. 673/2014, of the European Central Bank Concerning the Establishment of a Mediation Panel and its Rules of Procedure, 2014 O.J. (L 179) 72 [hereinafter: Mediation Panel Regulation] Rec. (4) and Art. 3(1) www.ecb.europa.eu/ecb/legal/pdf/celex_32014r0673_en_txt.pdf (accessed 25 September 2020).

${ }^{91}$ Art. 25(5) and Mediation Panel Regulation Art. 4(1) SSMR. For the specifics of the voting procedure see also: Regulation (EU) No 673/2014 of the European Central Bank Concerning the Establishment of a Mediation Panel and its Rules of Procedure ECB/2014/26' [2014] OJ L 179/72 [hereinafter: Mediation Panel Regulation], Art. 7.

${ }^{92}$ Art. 13k (3) ECB Rules of Procedure.

${ }^{93}$ The Governing Council consists of the members of ECB's executive board and the Governors of NCBs of the Eurozone Member States - Art. 283(1) TFEU and Art. 10 ESCB Statute.

${ }^{94}$ See also Art. 9(3) ESCB Statute.
} 
Governing Council and the executive board. In fact, during the negotiation process of the SSM, it was highlighted that according to EU primary law, the only decision-making bodies of the ECB are the Governing Council and the Executive Board and that since the treaty does not provide for an amendment of these bodies, the establishment of a new supervisory is in breach of Article 13(2) TEU and goes beyond the wording of Article 127(6). ${ }^{95}$ It follows that the SSB, hierarchically, stands below the Governing Council, given that it does not have any legally binding decision-making powers. In fact, the SSB has been established to serve as the internal body of the SSM, responsible for the planning and preparation of draft decisions on supervisory matters. The latter are subject to the final decision of the Governing Council, which remains the body that produces the legally binding decisions of the ECB. ${ }^{96}$ This is also highlighted in the ECB Rules of Procedure, Article 13a, which reads as follows: 'any tasks of the Supervisory Board shall be without prejudice to the competences of the ECB decision-making bodies.' It follows that the objectivity of the Governing Council members is also questionable, since the same individuals that would carry out monetary policy tasks would be called eventually to decide on supervisory matters. This is regulated to a certain degree by the added provisions in the amended Rules of Procedure of the ECB, which require the Governing Council to arrange separate meetings for monetary policy and for supervisory matters. ${ }^{97}$ However, the issue of impartiality as to the participation of the same members in both functions' decision-making process still remains blurry.

A true 'Chinese Wall' between monetary policy and banking supervision requires a balance between the two functions and equal prominence of the main bodies of each. In our case, equal prominence of the Governing Council and the SSB is not achievable since, by EU primary law, the Governing Council constitutes the main decision body of the ECB, and thus every change in this respect would require treaty amendment. In fact, the scenario of treaty amendment was also argued by those who believed that the existing treaty provisions do not allow for empowerment of the ECB with supervisory powers. ${ }^{98}$ Notably, the treaty amendment scenario could be possible and finds legitimate ground in the wording of Recital (85) SSMR, which emphasizes that there are 'some legal constraints' in the SSM design, which only treaty amendment could overcome. Furthermore, Recital (85) SSMR, when referring to the possibility of potential amendments, points to Article 127(6) TFEU, which constitutes the legal basis of the ECB operation. Therefore, this indicates that the SSMR acknowledges that there are still legal constraints in regard to the separation of monetary policy and supervision, which could be addressed only by amending the treaty. It might therefore take another major financial crisis to bring us back to the realization that the combination of national and supranational elements within a

\footnotetext{
${ }^{95}$ Stanyo Neykov Dinov, 'The European Central Bank and Its Role in the New European System of Banking Supervision' (2017) 134 (1) Banking Law Journal 38, 49. See also Opinion of the Legal Service of the European Council of 9 October 2012.

${ }^{96}$ Rec. (67) and Art. 26(8) SSMR and Art. 13a ECB Rules of Procedure.

${ }^{97}$ Art. 13l(1) ECB 2014 Decision.

${ }^{98}$ Kern Alexander, 'The European Central Bank and Banking Supervision: The Regulatory Limits of the Single Supervisory Mechanism’ (2016) 24 (13) European Company and Financial Law Review 467, 479.
} 
highly integrated financial system of a common currency and common regulatory framework is not sufficient in maintaining the soundness of the financial system as a whole.

\section{The Two Levels of the ECB's Independence}

\section{Independence in Monetary Policy Operations}

According to Article 127(2) TFEU, 'the primary objective of the European System of Central Banks shall be to maintain price stability.' In addition, according to Article 130 TFEU, to deliver on its mandate, the ECB should act in full independence from any EU institution, body, office and agency and from the governments of Member States, ${ }^{99}$ whereas the latter shall

respect this principle and not to seek to influence the members of the decision-making bodies of the European Central Bank or of the national central banks in the performance of their tasks. ${ }^{100}$

It is clear that the wording of Article 130 TFEU explicitly forbids the members of the ESCB's Governing Council from taking instructions from any national or EU body, thus establishing a high level of institutional independence, which implies a broad discretion in monetary policy decision making. ${ }^{101}$

The ECB also enjoys instrument independence, which means that it is up to the Bank's discretion to decide the definition of price stability and the means of achieving it. In particular, the ECB holds the power to define and implement monetary policy exclusively ${ }^{102}$ and is also the responsible body for banknote issuance. ${ }^{103}$ The ECB also enjoys a high level of personal independence, which refers to the autonomy of the internal bodies' members of the ECB. In particular, the Governors of the NCBs and members of the executive board are granted, at least, five- and eight-year office terms, respectively. ${ }^{104}$ Also, the ECB has financial independence that is related to its capacity to cover and organize the funding of its own operation and activities. This refers to its exclusive power to issue the euro and to manage its finances. ${ }^{105}$ Lastly, the independence of the ECB has been confirmed by the European Court of Justice (ECJ) in its so-called OLAF ruling, ${ }^{106}$ where it examined the validity of the

\footnotetext{
${ }^{99}$ See also: Art. 282(3) TFEU and Art. 7 ESCB Statute.

100 Art. 130 TFEU.

${ }^{101}$ Case C-62/14, Gauweiler and Others v. Deutscher Bundestag [2015] E.C.R. I-400, Para. 75.

102 Art. 127(2) TFEU and Art. 3.1 ESCB Statute.

103 TFEU Art. 128(1) and ESCB Statute Art. 16.

${ }^{104}$ Art. 128(1) TFEU and Art. 16 ESCB Statute.

105 Art. 282 TFEU.

${ }^{106}$ Case C-11/00 Commission v European Central Bank [2003] ECR I-7147 (hereinafter: OLAF case).
} 
ECB's decision in regard to fraud prevention, which also established the European Anti-Fraud Office (OLAF). ${ }^{107}$ While examining the constitutional nature of the ECB and the scope of its independence, the ECJ highlighted that

the draftsmen of the EC Treaty clearly intended to ensure that the ECB should be in a position to carry out independently the tasks conferred upon it by the Treaty. ${ }^{108}$

In essence, the principle of ECB independence is essential to its instructional design and a prerequisite for the performance of its core monetary policy role. However, the operational structure of the ECB, along with its independence, as originally laid down in the EU Treaty, was unambiguously designed and formulated to serve a central bank that was intended to be focused on the sole mandate of price stability. With the advent of the SSM, the ECB is no longer only a price stability-oriented monetary authority but has become the major supranational supervisory authority for the Eurozone, having to coordinate and maintain a balance between the two sets of operations. The banking supervision operations of the ECB cover mainly micro-prudential supervision and some limited macroprudential tasks in the pursuit of financial stability. Thus, one might raise the question of whether the same provisions regarding the ECB's monetary policy mandate, including the independent status of its operation, apply equally to the ECB's newly assigned supervisory tasks.

\section{Independence of Supervisory Operations}

It has been argued that Article $130 \mathrm{TFEU}$, and therefore the principle of independence, applied equally to the supervisory powers of the ECB. ${ }^{109}$ Indeed, according to the provisions of the SSMR, it is clear that the aim is to safeguard the ECB's independence with respect to its supervisory tasks too. To this end, Recital (75) SSMR provides that:

in order to carry out its supervisory tasks effectively, the ECB should exercise the supervisory tasks conferred on it in full independence, in particular free from undue political influence and from industry interference which would affect its operational independence. ${ }^{110}$

For a thorough analysis of the OLAF case see Roger Goebel, 'Court of Justice Oversight Over the European Central Bank: Delimiting the ECB's Constitutional Autonomy and Independence in the OLAF Judgment' (2005) 29 (4) Fordham International Law Journal 609.

107 'Decision of the European Central Bank of 7 October 1999 on fraud prevention (ECB/1999/5)' [1999] OJ L 291/36.

${ }^{108}$ OLAF case (n 105) Para. 126.

${ }^{109}$ Chiara Zilioli, 'The Independence of the European Central Bank and Its New Banking Supervisory Competences', in Dominique Ritleng (ed.), Independence and Legitimacy in the Institutional System of the European Union (OUP 2016) 164.

${ }^{110}$ See also: Code of Conduct for high-level European Central Bank Officials [2019] OJ C 89 [hereinafter ECB Code of Conduct] Art. 6. 
In addition, the members and alternates of the supervisory bodies are expected to act honestly, independently, impartially, with discretion and without regard to self-interest. ${ }^{111}$ Moreover, they are required to act independently and objectively in the interest of the Union as a whole, while they are prohibited from seeking or take any instructions from the institutions or bodies of the EU or any government of a Member State or from any other public or private body, and the latter are obliged to respect their independence. ${ }^{112}$ This is considered to be a broadly formulated independence, and, as such, is unclear and largely theoretical. ${ }^{113}$

The SSB is complemented by a new body called the steering committee, with no decisionmaking power, whose role is limited to carrying out tasks that are preparatory and supportive of the SSB tasks, with the main responsibility of preparing the meetings of the SSB. ${ }^{114}$ The steering committee members should carry out their tasks 'solely in the interest of the Union as a whole, and work in full transparency with the Supervisory Board. ${ }^{115}$ The members of both the SSB and the steering committee are granted, by the SSMR and SSB Code of Conduct, a high level of independence, aimed at protecting them from any political interference. ${ }^{116}$ Article 4 SSB Code of Conduct extends independence beyond the members of the SSB, including all the participants in the meetings of the SSB, who are required to perform their supervisory tasks 'free from undue political influence and from commercial interference', ${ }^{117}$ while they should avoid or even resign from positions that 'could hinder their independence or present them with the possibility of using privileged information'. ${ }^{118}$ Private financial transactions of the members and participants of the SSB, including their personal assets, are also subject to the notion of independence. ${ }^{119}$

In addition, the term of office of the SSB chair shall not exceed five years and is not renewable, while the independence of the SSB members and all supervisory body members is subject to coolingoff periods and appropriate compensation, after their office term has expired. ${ }^{120}$ In particular, the SSB members and any participant should wait for one year and six months, respectively, after the expiry of their office terms, in order to get involved in occupational activities concerning credit institutions directly supervised by the ECB, or in relation to financial institutions non-directly supervised by the

\footnotetext{
${ }^{111}$ Art. 3(2) SSB Code of Conduct.

${ }^{112}$ Rec. (71), Art. 19(1), (2) SSMR; Art. 6 ECB Code of Conduct; and Rec. (1) and Art. 4(1) SSB Code of Conduct.

${ }^{113}$ Eddy Wymeersch, 'The Single Supervisory Mechanism or "SSM", Part one of the Banking Union' (2014) European Corporate Governance Institute (ECGI) - Law Working Paper No. 240, 25, https://papers.ssrn.com/sol3/papers.cfm?abstract_id=2397800 (accessed 25 September 2020).

${ }^{114}$ Rec. (71) and Art. 26(10) SSMR and Art. 10 ECB Rules of Procedure.

115 Rec. (71) SSMR.

116 Art. 19(1), (2) SSMR, SSMR Rec. (71), and Rec. (1) and Art. 4(1) SSB Code of Conduct.

117 Art. 4(2) SSB Code of Conduct.

118 Art. 4(3) SSB Code of Conduct.

119 Art. 5(1) SSB Code of Conduct.

${ }^{120}$ Arts. 8(1) (a-c) and (2), (a-c). SSB Code of Conduct.
} 
ECB, but 'where a conflict of interest exists or could be perceived to exist'; or six months for the SSB members or three months for any other participant in the SSB meetings, when the occupational activity involves a non-credit institution, 'save where a conflict of interest exists or could be perceived to exist'. ${ }^{121}$ The cooling-off period of occupational activities concerning banks directly supervised by the ECB are subject to an extension of a maximum of two years for the SSB members and a maximum of one year for any other participant, after the relevant recommendation of the ECB's ethics committee: 'where the possibility of conflicts of interest resulting from subsequent occupational activities cannot be excluded for longer periods'. ${ }^{122}$ In any case, the members of SSB and any other participant in the SSB meetings shall inform the ECB President of their intention to get involved in any occupational activities in a one-year period, for any other participant in a two-year period, for the SSB members post their office term expiry, including non-profit activities. ${ }^{123}$

Furthermore, the members and other participants in the SSB meetings are subject to strict rules in order to avoid any conflict of interest situations concerning private or personal factors that may influence the objectivity of their performance. These shall be disclosed in writing in order to exclude them from their voting rights. ${ }^{124}$ The same restrictions apply to their spouse or recognized partner, which should be reported to the ethics committee. ${ }^{125}$ The objectivity of the members or other participants in the SSB meetings is also subject to specific rules as regards the acceptance of gifts or other benefits, which should be in accordance with Article 10 SSB Code of Conduct. The members and any participant in the SSB meetings should also pay particular attention to: a) their public appearances, including the prudence of their invitation, in conferences, receptions, cultural events, connected entertainment and appropriate hospitality, which should comply with the principle of independence; ${ }^{126}$ b) the activities undertaken in their personal capacity, which should comply with their professional obligations, the reputation of the ECB, excluding the academic activities. ${ }^{127}$ Moreover, according to Recital (74) SSMR, the members or participants in the SSB meetings shall comply with the professional secrecy rules. ${ }^{128}$

Private financial transactions of the members of and participants in the SSB, including their personal assets, are also subject to the notion of independence. Specifically, confidential information arising from private financial transactions, to which they have access either directly or via third parties, at their own risk and on their own account or at the risk and on the account of a third party, are not permitted to be used by the members of or any participant in the SSB. ${ }^{129}$ Moreover, their personals

${ }^{121}$ SSB Code of Conduct Arts. 8(1)(a-c) and (2), (a-c).

${ }^{122}$ Art. 8(4) ASSB Code of Conduct.

${ }^{123}$ Art. 8(1) and (2) SSB Code of Conduct.

${ }^{124}$ Art. 9 SSB Code of Conduct.

125 Art. 13 SSB Code of Conduct.

${ }^{126}$ Art. 11(1) SSB Code of Conduct.

${ }^{127}$ Art. 12 SSB Code of Conduct.

${ }^{128}$ Art. 37 ESCB Statute; Art. 27(1) SSMR; Art. 23a ECB Rules of Procedure; Art. 14(1) SSB Code of Conduct.

${ }^{129}$ Art. 5(1) SSB Code of Conduct. 
assets, which go beyond those required for family use, shall be organized in a way that would ensure their independence and would also be subject to the rules on private transactions adopted by the ECB for its members of staff; or if the members or participant of the SSB represent the NCAs, they would be subject to the relevant national rules. ${ }^{130}$

The same level of independence applies to the Administrative Board of Review (ABoR) members, who shall act independently and in the public interest and are not bound by any instructions. ${ }^{131}$ In addition, the staff of ECB, or NCAs, or any other staff from national or Union institutions, bodies, offices and agencies, who are involved in supervisory tasks, cannot be nominated to be appointed as ABoR members or alternates. ${ }^{132}$ Appointments of ABoR members are made by the Governing Council, on the basis of a geographical and gender balance across the Member States, for a term of office of five years, renewable only once. ${ }^{133}$

\section{Does the Same Level of Independence Apply Equally in Both Domains?}

When it comes to evaluating central bank independence a few practical components are required to be considered. Monetary policy involves a measurable objective, i.e. achieving price stability by keeping inflation rates at a clearly defined leve ${ }^{134}$ and maintaining low unemployment rates. In contrast, banking supervision involves a wide range of tasks and objectives, including financial stability, consumer protection and financial crime, and often utilizes more regulatory tools in their pursuit and also requires a combination of financial, accounting and legal expertise. ${ }^{135}$ The main challenge of banking supervision is that the prerequisites for achieving these objectives are practically difficult to address. As Mersch rightly opined, it is difficult to define the clear objectives in relation to financial stability, which makes it challenging to measure the performance of independent, expertisebased institutions and hold them to account. ${ }^{136}$

When it comes to the ECB's independence, apart from all the specific provisions mentioned previously, it is undisputed that one of the main mechanisms to safeguard the principle of independence,

\footnotetext{
${ }^{130}$ Art. 5(2), (3) SSB Code of Conduct.

131 'Decision of the ECB of 14 April 2014 concerning the establishment of an Administrative Board of Review and its Operating Rules (ECB/2014/16)' [2014] OJ L 175/47 [hereinafter: Administrative Board Decision], Art. 24 (2) and (4); Art. 4(4).

132 Art. 24(2) SSMR.

${ }^{133}$ Rec. (64) and Art. 24(2) SSMR; Art. 4(1) and (3) Administrative Board Decision.

${ }^{134}$ The ECB aims at inflation rates of below, but close to, $2 \%$ over the medium term. See: ECB, 'Monetary

Policy', www.ecb.europa.eu/mopo/html/index.en.html (accessed 25 September 2020).

${ }^{135}$ Rosa Lastra, 'Banking Union and Single Market: Conflict or Companionship?' (2013) 36 (5) Fordham International Law Journal 1190, 1197.

${ }^{136}$ Yves Mersch, 'Financial Stability and the European Central Bank' (BIS, 2018), www.bis.org/review/r180906a.htm\#footnote-21 (accessed 25 September 2020).
} 
in the monetary policy and supervisory domains, is the requirement of organizational separation of staff concerning

all services needed for independent monetary policy purpose and should ensure that the exercise of the tasks conferred by this Regulation is fully subject to democratic accountability and oversight as provided for by this Regulation. ${ }^{137}$

As discussed earlier in this article, such a strict separation has hardly been achieved, mainly because of the clearly increased involvement of the Governing Council in supervisory domain and the interdependence of both monetary policy and supervisory operations of the ECB. As Alexander has argued, in fact, the current regulatory framework does not provide the ECB with the adequate institutional capacity and legal competence to carry out effective banking supervision, which calls for further institutional and legal changes, including the possibility of treaty amendment. ${ }^{138}$

Moving beyond the questions raised from the separation between the ECB's monetary policy and supervision domains, there are also issues of legitimacy that come into play. ${ }^{139}$ To this end, the functioning of monetary policy and supervision are fundamentally different. With regard to monetary policy, as analysed earlier, the ECB's independent status derives its legitimacy from EU primary law. To this end, the wording of the EU Treaties' provisions has equipped the ECB with a high level of discretion when carrying out its monetary policy tasks, meaning that the ECB is not directly accountable to the EU Parliament, the EU Council, or to any other national or EU body for its day-to-day decisions,, and its decisions are not subject to approval. Also, apart from the ECJ, ${ }^{140}$ none of the EU institutions or national bodies have the power to discharge any of the members of ECB decision-making bodies. ${ }^{141}$ Thus, the ECB retains its legitimacy to make policy decisions, provided only that it operates within the limits of its mandate as provided by EU law. When it comes to its supervisory powers on the other hand, while the legitimacy of the conferral of supervisory tasks is based on the treaty, the legal instrument that specifies those tasks, i.e. the SSM Regulation, constitutes secondary EU law. Thus, it

\footnotetext{
${ }^{137}$ Rec. (66) SSMR.

138 Alexander (n 97) 482.

139 This also links with the relevant debate on the democratic legitimacy of non-majoritarian institutions, which flourished in light of the increasing number and importance of independent unelected bodies empowered to regulate markets. For the relevant debate see: Martha S. Feldman and Anne M. Khademian, 'To Manage is to Govern' (2002) 62 (5) Public Administration Review 541; Giandomenico Majone, 'Europe's Democratic Deficit: The Question of Standards' (1998) 4 (1) European Law Journal 5; Giandomenico Majone, 'The Regulatory State and Its Legitimacy Problems' (1999) 22 (1) West European Politics 1; Giandomenico Majone, 'Nonmajoritarian Institutions and the Limits of Democratic Governance: A Political Transaction-Cost Approach' (2001) 157 Journal of Institutional and Theoretical Economics 5; K. Van Kersbergen and F. Van Waarden, 'Governance' as a Bridge between Disciplines: Cross-Disciplinary Inspiration Regarding Shifts in Governance and Problems of Governability, Accountability and Legitimacy’ (2004) 43 (2) European Journal of Political Research 143.

${ }^{140}$ Note: the ECB is subject to judicial control from the ECJ, Art. 263 TFEU. See also: OLAF case (n 105).

${ }^{141}$ Arts. 11(4) and 14(2) ESCB Statute.
} 
could be argued that, by default, as long as the ECB stays within the limits of its supervisory mandate, it is legitimate to make supervisory decisions. There is, however, a growing literature arguing in favour of the view that an independent bank empowered with supervisory tasks should be equipped with a strong accountability mechanism. ${ }^{142}$

Therefore, despite the effort to create a strict operational separation between the two functions, it is questionable whether the Treaty provisions that are designed to protect the independence of ECB's monetary policy mandate could be adequate in safeguarding the independence of its supervision mandate. This is particularly problematic in terms of instrumental/operational independence, which, when referring to monetary policy, implies a central bank's ability to decide independently when adjusting its short-term interest rates to achieve its inflation goal, which, as mentioned earlier, is a measurable objective, whereas, when referring to banking supervision, involves decisions such as putting financial institutions under statutory management, which cannot be measures. ${ }^{143}$ In short, the conduct of monetary policy and supervision by the same authority, i.e. the central bank, may lead to more elastic monetary policy strategies, in an attempt to prevent a banking crisis. It also seems that there are a few aspects of ECB's involvement in macro-prudential supervision that need careful consideration.

\section{E The Role of the ECB in Micro- and Macro-Prudential Supervision}

A closer look at the wording of Article 127(6) TFEU makes it clear that the limit of the ECB's supervisory powers in the micro-prudential domain is their 'specificity'. According to Article 127(6) TFEU:

The Council, acting by means of regulations in accordance with a special legislative procedure, may unanimously, and after consulting the European Parliament and the European Central Bank, confer specific tasks upon the European Central Bank concerning policies relating to the prudential supervision of credit institutions and other financial institutions with the exception of insurance undertakings. ${ }^{144}$

This specificity requirement imposes restrictions on the scope of the ECB's supervisory powers since anything beyond specific falls outside of the ECB's scope. This, in turn, unavoidably empowers the NCAs with the supervision of areas that the ECB does not, or is not permitted to, reach. As a result, the newly created system of EU banking supervision is far from achieving the intended outcome, i.e. a truly

\footnotetext{
142 Zilioli (n 108).

${ }^{143}$ BIS, 'Issues in the Governance of Central Banks: A Report from the Central Bank Governance Group'

(2009), 53 www.bis.org/publ/othp04.pdf (accessed 20 September 2020).

144 127(6) TFEU, emphasis added.
} 
centralized system of banking supervision for Europe. The existing structure has led to the creation of a rather complex system of shared responsibilities and cooperation between the national and supranational levels. As Alexander argues, for the ECB to be an effective bank supervisor requires more coordination between the ECB's supervisory and monetary policy operations. ${ }^{145}$

At the macro-prudential level, the ECB's involvement is two-fold. First, the ECB has assumed a few macro-prudential tools, for instance, inter alia, the assessment and monitoring of capital adequacy, ${ }^{146}$ liquidity buffers ${ }^{147}$ and leverage limits, ${ }^{148}$ and, when deemed necessary, may also impose higher, than the local NCA, requirements for capital buffers' prudential requirements. ${ }^{149}$ Notably, the ECB has also additional powers in the context of the ESRB, ${ }^{150}$ which represents the macro-prudential pillar of European System of Financial Supervision (ESFS) and is entrusted with the responsibility of macro-prudential supervision of the EU financial system and the prevention and mitigation of systemic risk. ${ }^{151}$ The establishment of SSM did not bring any substantial amendments to the operation of ESRB. However, the conferral of macro-prudential responsibilities on the ECB through the SSMR may prove challenging to the existing powers of the ESRB, including the division of responsibilities between the ECB and ESRB and their cooperation. All these combined raise questions as to the balance of powers between the ECB and the ESRB.

Indeed, the SSMR does not provide explicit answers with regard to the role of the ESRB within the new supervisory framework. The only reference made to the ESRB is in Recital (31) and Article 3(1) (subparagraph 1) SSMR, both highlighting that the ECB would have to perform its supervisory tasks in close cooperation with the ESRB, yet according to Article 25(2), the ECB is to perform the conferred supervisory tasks without interfering with the ESRB's tasks. However, the ECB plays an active role in the ESRB's operations. In fact, the ESRB is be chaired by the ECB President, supported by the Secretariat of the ECB, and is composed mainly of the members of ECB/ESCB General Council (along with the chairpersons of Level 3 committees as well as one representative of the EU Commission), drawing on technical advice from all EU national central banks and supervisors.

Apart from its already leading role in the ESRB operation, the ECB is provided with the discretion to request an increase in the requirements for capital buffers and the right to object to decisions of the NCAs as regards macro-prudential matters, regardless of whether they are based on the

\footnotetext{
145 Alexander (n 97) 467.

146 Art. 4(1)(e) SSMR.

147 Art. 4(1)(d) and Art. 5 SSMR.

148 Art. 4(1)(d) SSMR.

149 Art. 5 SSMR.

150 The ESRB became operational on 1 January 2011. For the relevant regulation see: Council Regulation (EU) No. 1096/2010 of 17 November 2010, conferring specific tasks upon the European Central Bank concerning the functioning of the European Systemic Risk Board [2010] OJ L331/162 [hereinafter ESRB Regulation].

${ }^{151}$ Art. 3(1) ESRB Regulation.
} 
ESRB's specific recommendations to the NCAs. ${ }^{152}$ Thus, within this structure, although the NCAs have retained their prominent role in macro-prudential supervision, the ECB is also granted key responsibilities that may overlap or even create conflicting issues with the existing role of the ESRB. This issue is not clearly addressed by the SSMR and leaves space for broad interpretations, including the possibility of centralization of macro-prudential powers at the EU level. The latter is seen positively by the supporters of the view that the macro-prudential supervision should be carried out explicitly by the ECB in the name of stability. ${ }^{153}$ A counterargument as to the overlapping issue could be based on the wording of Article 25(2), SSMR, according to which any interference of ECB's supervisory tasks in the respective ESRB tasks is prohibited. Also, Recital (24), SSMR, highlights that 'the provisions in this Regulation on measures aimed at addressing systemic or macro-prudential risk are without prejudice to any coordination procedures provided for in other acts of Union law'.

To this end, Vitor Constancio, the vice president of the ECB, in an attempt to highlight the compatibility between the respective roles of ECB and ESRB in macro-prudential supervision, emphasized that the macro-prudential functions of both institutions (ECB and ESRB) are expected to be complementary and:

while the SSM will exclusively focus on banking systems, the ESRB has an additional macroprudential function regarding the nonbank parts of the financial sector, and as such will be well placed to address cross-sectoral issues. ${ }^{154}$

In addition, the involvement of the ECB in macro-prudential tasks through its participation in the ESRB is particularly problematic, given the lack of an adequate legal basis. As already highlighted, the ECB is excluded from undertaking macro-prudential tasks that do not qualify as specific, without treaty amendment.

However, experience has shown that for supervision the scenario is different and that a mixture of factors might lead to results that are likely to prejudice the ECB's independence. A good example is the role of the ECB during the GFC, especially in relation to Greece, when the ECB was faced with the dilemma of whether to cut off emergency funding to Greece provided through the Emergency Liquidity Assistance (ELA). To this end the ECB's decision to limit emergency funding to Greece in 2015 raised questions in terms of its independence. In particular, this move was considered as an act of politicization of the ECB and as an example of central bank dependence, since a decision of the ECB to cut off ELA

\footnotetext{
152 Art. 5 SSMR.

${ }^{153}$ Gianni Lo Schiavo, 'From National Banking Supervision to a Centralized Model of Prudential Supervision in Europe? The Stability Function of the Single Supervisory Mechanism' (2014) 21 (1) Maastricht Journal of European Comparative Law 110, 133.

${ }^{154}$ Vítor Constâncio, 'Implications of the SSM on the ESFS' (Speech by the Vice-President of the ECB, Public Hearing on Financial Supervision in the EU, Brussels, 24 May 2013), www.ecb.europa.eu/press/key/date/2013/html/sp130524.en.html (accessed 20 September 2020).
} 
could have amounted to de facto forcing Greece out of the euro, which in itself constitutes a highly political decision. ${ }^{155}$ This perhaps explains why, in the end, the ECB decided to maintain emergency funding, albeit at carefully calibrated levels. ${ }^{156}$ As Mario Draghi, the President of ECB, stated: 'The ECB is a rule-based institution. It's not a political institution. ${ }^{157}$ This discussion is also related to the role of ECB as lender of last resort, which has not been adequately addressed by the SSM Regulation or by any relevant legislative act.

Even more recently, the independence of the ECB and the constitutional foundation of monetary policy came again under scrutiny in light of the ruling of the German Federal Constitutional Court (GFCC) of 5 May $2020^{158}$ concerning the ECB's purchases of sovereign debt in light of the implementation of its public sector purchase programme (PSPP) of $2015 .{ }^{159}$ According to the GFCC, the ECB has acted ultra vires, by exceeding its powers as provided by EU primary law. The ruling was not, in the main, against the ECB's decision to implement the PSPP but focused on the fact that the ECB did not comply with the principle of proportionality. To this end, the GFCC argued that the ECB should act within the limits of its powers by undertaking only monetary policy operation, while economic policies shall remain a responsibility at the national level. The GFCC also goes so far as to criticize the ECJ for exceeding its judicial mandate and for not applying the principle of proportionality, and thus its ruling was also ulra vires. ${ }^{160} \mathrm{As}$ a result, the GFCC asks the ECB to conduct a proportionality assessment. As the GFCC underlines, 'They must clearly communicate their legal view to the European Central Bank or take other steps to ensure that conformity with the Treaties is restored' ${ }^{161}$ The ruling has sparked a debate on the constitutional basis of ECB's Treaty mandate and also poses a direct challenge to its independence. ${ }^{162}$ Notably, this is not the first time that the GFCC has questioned the powers of the ECB. The GFCC has, in the past, openly questioned the legality of the outright monetary

\footnotetext{
${ }^{155}$ Charles Wyplosz, 'Grexit: The Staggering Cost of Central Bank Dependence' (Voxeu 29 June 2015), http://voxeu.org/article/grexit-staggering-cost-central-bank-dependence (accessed 20 September 2020). See also: Claire Jones, 'ECB Weighs Pulling Plug on Greek Banks' (FT, 18 February 2015), www.ft.com/content/64f6e8d4-b6b8-11e4-95dc-00144feab7de?mhq5j=e3 (accessed 20 September 2020). ${ }^{156}$ ECB, 'ELA to Greek Banks Maintained at Its Current Level' (Press Release, 28 June 2015), www.ecb.europa.eu/press/pr/date/2015/html/pr150628.en.html_accessed 20 September 2020). ${ }^{157}$ Mario Draghi, 'Introductory Statement to the Press Conference (with Q\&A)' (5 March 2015), www.ecb.europa.eu/press/pressconf/2015/html/is150305.en.html (accessed 20 September 2020). ${ }^{158}$ BVerfG, Judgment of the Second Senate of 05 May 2020 - 2 BvR 859/15, Paras. 1-237.

159 'ECB Announces Expanded Asset Purchase Programme' (ECB, 22 January 2015), www.ecb.europa.eu/press/pr/date/2015/html/pr150122_1.en.html (accessed 20 September 2020). For the decision see: 'Decision of the European Central Bank of 4 March 2015 on a Secondary Markets Public Sector Asset Purchase Programme (EU/2015/774)' [2015] OJ L 121/20, as amended by 'Decision of the European Central Bank of 11 January 2017 (EU/2017/100)' [2017] OJ 2017 L 16/51. ${ }^{160}$ C-493/17 Heinrich Weiss and others v. Deutscher Bundestag [2018] ECLI I-1000.

${ }^{161}$ BVerfG, Judgment of the Second Senate of 05 May 2020 - 2 BvR 859/15.

162 Peter Bofinger, Martin Hellwig, Michael Hüther, Monika Schnitzer, Moritz Schularick and Suntram B. Wolff, 'The Independence of the Central Bank at Risk' (Bruegel, June 2020), www.bruegel.org/2020/06/theindependence-of-the-central-bank-at-risk/ (accessed 20 September 2020).

See also: Martin Wolf, 'German Court Decides to Take Back Control with ECB Ruling' (FT, 12 May 2020), www.ft.com/content/37825304-9428-11ea-af4b-499244625ac4 (accessed 20 September 2020).
} 
transactions (OMT) programme, the ECB's government bond purchase programme, in the infamous Gauweiler ruling - a question that was then dismissed by the ECJ.

From the foregoing analysis, it can be argued that the centralization of supervisory powers, although not appearing to pose any immediate risk to ECB's independent status, leaves important gaps in its overall independence. The detailed provisions on the role, tasks and responsibilities of the members that form the ECB's decision-making bodies with regard to micro-prudential supervision appear to be adequate in shielding their independent operation. However, as mentioned earlier, since the means to achieve the objectives of monetary stability and banking supervision are fundamentally different, it is debatable whether the same treaty provisions can be adequate for both. More controversial is the principle of separation between the monetary policy and the supervisory powers of the ECB, which appears to be far from ideal. The same applies to the macro-prudential powers of the ECB both within the SSM and the ESRB, which, as discussed earlier, leave space for broad interpretation. It is therefore necessary to reconsider the treaty provisions providing the legal basis of the ECB and, potentially, amend them in order to create a solid legal basis for the ECB's powers in both domains.

\section{F Conclusion}

The ECB, in November 2014, officially became the micro-prudential supervisor of the financial institutions in the Eurozone. Since 2014 a host of legislative initiatives have been introduced, aimed at strengthening the ECB's supervisory function and defining the responsibilities between the ECB and the existing bodies. This has resulted in a complex system resting on an edifice of legislative measures that complement each other in a peculiar manner. Since the inception of the idea to centralize EU banking supervision, the debate on the synergies, legal constraints and its long-term sufficiency has only been increasing. Yet the issues in question, including the ECB's independence, the balance of powers between the EU institutions and the conflict of interest between monetary and supervisory powers, remain unresolved.

As analysed, the clear distinction between ECB monetary policy and supervisory powers is not straightforward and the intended creation of a strong 'Chinese Wall' between the two functions is not always feasible within the current legal framework. In particular, the stringency of the separation principle that intends to retain a clear distinction between the monetary policy and banking supervision responsibilities of the ECB has lapses and gaps that are not clearly defined by the SSMR.

In relation to the ECB's independence, the governance arrangements in light of its involvement in banking supervision are potentially troubling: while a separate body (i.e. the SSB) has been created in order to deal with exclusively with supervisory matters, the fact that the Governing Council retains the final decision-making power may create undue institutional complexity. This is also not compatible 
with the ring fence that should be maintained between supervision and monetary policy as explicitly defined by the SSMR. Housing monetary policy and supervision objectives under the same roof is likely to endanger central banks' instrumental/operational independence, often as a result of the loose monetary policies that central banks often pursue in an attempt to prevent (or address) a banking crisis. In addition, the macro-prudential role of the ECB in both the SSM and the ESRB remains blurry and also raises concerns that may place the constitutional basis of the ECB's legal powers and its independence under scrutiny. To this end, it is suggested that the only avenue towards transforming the ECB into a truly supranational supervisor with full discretion, while retaining its independence, is the amendment of the treaty and the empowerment of the ECB with clearly defined, direct supervisory powers. 